\title{
Civic Education as Vehicle of Multicultural Education in Building Democratic Citizen
}

\author{
Candra Cuga \\ State University of Gorontalo \\ Gorontalo, Indonesia \\ candracuga@ung.ac.id
}

\begin{abstract}
This study is departed from researcher anxiety toward the lack of Civic Education learning in responding to the needs and condition of multicultural students so it needs Civic Education learning based on multicultural in higher education. As for the aim of this study is to find Civic Education material development and learning design as vehicle of multicultural education in building democratic citizen in higher education. This study used qualitative approach with grounded theory method and the data were obtained by observation, interview, literature study and documentation study techniques. Subject of study consisted of Civic Education and Sociology experts who pay attention to multicultural education study, lecturers and students of Primary School Teacher Education Department, Faculty of Pedagogy, State University of Jakarta. The result of this study revealed that the concept of Civic Education learning implementation as vehicle of multicultural education in Primary School Teacher Education Department, Faculty of Pedagogy, State University of Jakarta can be seen from two aspects, namely: first, material development had been done by integrating some materials related to multiculturalism such as nation integrity, multicultural education concept, relation between multicultural principle and nationalism in Indonesia, concept and essence of multiculturalism seen from philosophical, juridical and empirical aspect. Second, learning design had been arranged systematically, but there are still many learning components which should be developed among others are planning (learning goal, the competences which want to be achieved), learning source and material which do not utilize natural environment and community so its learning strategy and approach should be more varied and innovative. As for the finding result of grounded theory in this study is that the competence which want to be achieved should be based on citizen ability in "living the world life" with some core values which needs to be developed such as open minded, mutual trust, mutual understanding, diversity, mutual respect, living the life together and with others, self national identity and conflict resolution.
\end{abstract}

Keywords—civic competence; civic education; multicultural

\section{INTRODUCTION}

Civic education is one field of study in national education context which has strategic role for nation and character building in the midst of Indonesian society heterogeneity. That plurality and heterogeneity reality is described in the principle of unity in diversity. As multicultural nation, Indonesia should has multiculturalism awareness in order that the nation tribes who inhabit this region build healthy and dynamical interaction and communication to create democratic, harmonious, and peaceful society [1]. Therefore, Civic Education fined its momentum to be a central topic in building Indonesian nation and state. The multicultural Indonesian society cannot be build taken for granted or trial and error. In contrary, it should be strived for systematically, programmatically, and continuously. One strategy which is used to be done in that context is through civic education. Civic education here in civic education in broader meaning (citizenship education) which has $21 \mathrm{st}$ century world citizenship perspective which is well known with the name multi dimension citizenship with one characteristic has multicultural characteristic [2].

Based on that thinking, it can be understood that Civic Education has very strategic role in building citizen as good citizen. It is in accordance with Kerr who say that

Citizenship or civic education is construed broadly to encompass the preparation of young people for their roles and responsibilities as citizens and, in particular, the role of education (through schooling, teaching and learning) in that preparatory process or, "citizenship or civics education [3]

In that definition, it is described that Civic Education has role in fostering Indonesian citizens to become society who understand their duty and responsibility as citizen toward nation and state life in the context of Unitary State of Republic of Indonesia which hold the principle of diversity in unity. For that reason, Civic Education has very important role in the effort to develop multicultural society. It is as mentioned in Act No. 20 of 2003 about National Education System which had been principally contained in article (4), in which it is explained that "education is organized democratically and indiscriminative by upholding Human Right values, religious and cultural values" [4]. Based on that conception, higher education is one instrument in national education context in programming Civic Education in curricular as a place in fostering citizen to become good and smart. Therefore, higher education become setting which is chosen in this study, because it is one place in building citizen who will understand democracy value and multicultural principle itself. It is in accordance with Zuhria who express that [5]:

Higher education and educational institution are place to cultivate multiculturalism and democracy discourse. The tactical strategy of multiculturalism education is preserved to create generations who aware of cultural diversity, in 
addition giving theoretical base to search the causes of conflict and violence which touch with that diversity.

Higher education as formal educational institution is viewed as gate to do culture development task for students. So, higher education should has strategic power to create positive culture in accord with society philosophy. Appreciating society philosophy which include plurality means that there are educational characteristics which are oriented to multicultural interest. If that multicultural education approaches can be implemented, then the strong higher education culture will be born by itself in facing social problems in society. It is here the crucial function of Lembaga Pendidikan Tenaga Kependidikan (LPTK) as higher education institution which educate and prepare prospective teachers to equip and inculcate multicultural education to prospective teachers in its learning process [6].

In the book Multicultural Education: A Teacher Guide to Linking Context, Process and Content, the work of multicultural education expert in California State University, US, Hilda Hernandez define multicultural education as perspective which recognize political, social and economic reality experienced by each individual in humans encounter who have complex and diverse cultures, and reflect the importance of culture, race, sexuality and gender, ethnicity, religion, social, economic and political status, and exception in educational process [7]. That perspective can be understood that educational space as media for transfer of knowledge should be able to give multiculturalism values by valuing and respecting each other's the plural reality (pluralist), both social culture background and basis which comprise it.

Based on that thinking, higher education is educational level which is very strategic in developing multicultural education through Civic Education which is programmed in curricular which is more systematical and comprehensive. However, the question which then aroused is what kind of curricular program needed which capable to play role in building democratic citizen particularly in higher education?

Civic education as one of subjects taught in all levels and kinds of school pragmatically has psycho-pedagogical, that is, fostering democratic citizen in educational scope in formal and informal educational institution, Sapriya and Winataputra [8], state that the task of Civic Education in its new paradigm develop three basic functions, namely developing civic intelligence, fostering civic responsibility, and motivating civic participation. The civic intelligence developed to build good citizen not only in rational dimension but also in spiritual, emotional and social dimension so the new paradigm of Civic Education has multi dimension characteristic. Therefore, Civic Education with new paradigm mandate that democracy should be implemented smartly and culturally. So, it is not democracy which is implemented by forcing the willingness without packaged in the frame of legislation rule. If democracy is translated in destructive, intimidating way and without using commonsense, then it will result in anarchism so it deviates from democratic values and conflicted with the goal of Civic Education as mentioned in Content Standard of Civic Education (2006, page 2) which will develop the ability to: 1) think critically, rationally and creatively in responding to civic issues; 2) participate actively and responsibly, and act smartly in the activity in society, nation and state, and anti-corruption; 3) develop positively and democratically to build the self based on the characters of Indonesian society in order to be able to live together with another nations; 4) interact with another nations in world arena directly and indirectly by utilizing technology, information and communication.

Civic Education as vehicle of multicultural education not only inculcate better understanding about democracy, Human Right, pluralism, respect and tolerance among various communities, but also experience in democracy, civilization and multicultural. Therefore, it is expected that multicultural education can support democratic development which is growing in the midst of Indonesian nation which is multi ethnic, multi tribe, multi culture, multi religion, multi economic and politic toward Indonesian civil society or the new Indonesia idealized which capable to build citizens who have democratic awareness. Civic Education is one part of process to build multicultural style in strengthening nationality principle and appreciation toward diversity and to build citizen who aware of democracy value. But the reality in practice show that Civic Education less develop multicultural dimension, even loss its actuality because it only emphasize cognitive psychology which is trapped in merely knowledge mastery whereas another dimensions (affective and psychomotor) are ignored. One probable cause of this is because there is no clear concept for developing Civic Education based on multicultural education which is more systematical and comprehensive in higher education, so the practitioners in field had not seriously applied multicultural based- Civic Education in building democratic citizen.

From the background of thinking above, the researcher is interested to conduct a study about need analysis of multicultural education through competence based-Civic Education in building democratic citizen. This research is limited to a study which is intended to identify, do need analysis of Civic Education learning as vehicle of multicultural education in academic and curricular so it capable to find concept and strategy to implement multicultural education through Civic Education in higher education.

One higher education which become object of study in this study is higher education in Jakarta City namely State University of Jakarta in Primary School Teacher Education Department, Faculty of Pedagogy. The selection of setting for this study is because Primary School Teacher Education Department in State University of Jakarta had started to apply Civic Education learning as vehicle of multicultural education and there has been also Civic Education course namely Multicultural Education as option course developed by lecturer in Civic Education course. Besides, the students enrolled in that department are relatively heterogeneous seen from the aspects of tribe, religion, social and economic level so it is suited with the study which will be researched by the researcher.

\section{Method OF StUdy}

This study use qualitative approach with Grounded Theory method. Data collection technique used are: 1) literature study, this technique is done by reading, learning and studying 
literatures related to civic education, multicultural education, citizen, citizenship, multiculturalism, democracy. 2) interview, this technique is done directly between researcher and informants (civic education and sociology experts) by dialog, question-answer, discussion and through another way which enable to obtain the information needed in arranging and developing grounded theory. Besides, the researcher do faceto-face interview with participants, and involve in focus group interview consisting of 7 informants who are students. 3) Observation, to present realistic description about how the process and results of learning evaluation. Multicultural basedCivic Education in higher education, particularly in Primary School Teacher Department, State University of Jakarta is implemented by lecturers and students in lectures process in class. 4) Documentation to help analysis by utilizing bibliography source such as syllabus and SAP of Civic Education in Primary School Teacher Education Department, the assignments and lectures product (soft copy and hard copy), literature, paper, journal, and study result. Data analysis use three paths of activity which are done concurrently, namely: data reduction, data display, and conclusion drawing/verification. The validity of study data use three strategies in doing validation namely triangulate, apply member checking and use reference material.

\section{STUDY RESULT}

\section{A. The Development of Multicultural Material through Civic Education Learning in Building Democratic Citizen}

Based on finding of interview result with students, it is found some material content which are indeed in accord with what is delivered by lecturer who had applied Civic Education course based on multicultural education. Therefore, the researcher confirm that view with documentation result in the form of hard copy of SAP and syllabus of Civic Education course. It is found that some materials which had been delivered by lecturer had not contained or mentioned clearly. Only some materials which had been contained in syllabus and SAP of Civic Education course among others are: Identity and Integration of Indonesian Nation, The Essence of Multicultural in Globalization Era and Democratization of Indonesian Nation, Multicultural Concept Seen from Philosophical, Empirical and Juridical Perspective, Relation between Multiculturalism and Nationalism Spirit in Indonesia.

Based on interview result, documentation and observation in the field, the researcher can show the development of learning material of Civic Education based on multicultural education in Primary School Teacher Education Department, State University of Jakarta through following table.
TABLE I THE DEVELOPMENT OF LEARNING Material OF CiVIC EDUCATION BASED ON MULTICULTURAL EDUCATION IN PRIMARY SCHOOL TEACHER Education DEPARTMENT, Faculty of Pedagogy, State UNIVERSITY OF JAKARTA

\begin{tabular}{|c|c|}
\hline The Aspect Studied & Annotation \\
\hline \multirow[t]{2}{*}{$\begin{array}{l}\text { The development of } \\
\text { learning material of } \\
\text { Civic Education } \\
\text { based } \\
\text { multicultural } \\
\text { education. }\end{array}$} & $\begin{array}{l}\text { National identity material: the plurality of } \\
\text { Indonesian nation, nation identity and } \\
\text { integration, Human Right: material about the } \\
\text { dynamic of human life in culture and } \\
\text { personality as the essence of Human Right. } \\
\text { Democracy: the essence of multicultural in } \\
\text { globalization era and democratization of } \\
\text { Indonesian nation. }\end{array}$ \\
\hline & $\begin{array}{l}\text { There are some materials which had been } \\
\text { acquired by students in Civic Education course } \\
\text { among others are nation integrity, multicultural } \\
\text { education concept, relation between } \\
\text { multicultural principle and Indonesian } \\
\text { nationalism, concept and essence of } \\
\text { multiculturalism seen from philosophical, } \\
\text { juridical and empirical aspects. }\end{array}$ \\
\hline
\end{tabular}

a. Source: the processed primary source

Related to material development which is implemented in higher education, it shows that Civic Education as vehicle of multicultural education regarding its content can be strived for to integrate some material related to current context and learner need. But the important thing is it do not reduce or substitute the material which has formal structure. It shows that Civic Education as curricular program can become vehicle of multicultural education by developing some materials which is related to multicultural principle and multicultural education itself.

\section{B. Learning Design of Civic Education as Vehicle of Multicultural Education}

Based on interview result, documentation and observation in field, it can be described the use of learning design of Civic Education as vehicle of multicultural education in Primary School Teacher Education Department as shown in following table.

TABLE II. LEARNING DESIGN OF CIVIC EDUCATION AS VEHICLE OF Multicultural Education in Primary SCHOOL TEACHER EdUCATION DEPARTMENT, FACULTY OF PEDAGOGY, STATE UNIVERSITY OF JAKARTA

\begin{tabular}{|l|lr|l|}
\hline NO & \multicolumn{1}{|c|}{$\begin{array}{c}\text { The Aspect } \\
\text { Studied }\end{array}$} & \multicolumn{1}{c|}{ Annotation } \\
\hline 1 & $\begin{array}{l}\text { Syllabus and } \\
\text { Agenda } \\
\text { Lectures }\end{array}$ & $\begin{array}{l}\text { The syllabus of lectures contain about } \\
\text { assignment, reference/material and brief } \\
\text { description about the material presented in } \\
\text { lectures. } \\
\text { The agenda of lectures only discussed in } \\
\text { certain meeting. }\end{array}$ \\
\hline 2 & $\begin{array}{l}\text { The goal of } \\
\text { learning }\end{array}$ & $\begin{array}{l}\text { Foster and develop nationality insight and } \\
\text { grow the love toward motherland in } \\
\text { students as smart and good citizen in } \\
\text { accord with the goal of that course } \\
\text { program. } \\
\text { Equip and develop critical and reflective } \\
\text { thinking in students so they can become } \\
\text { citizens who have awareness of Unitarian } \\
\text { State of the Republic of Indonesia. } \\
\text { Grow and build students awareness to } \\
\text { become democratic citizen who are } \\
\text { civilized in accord with the ideal of }\end{array}$ \\
\hline
\end{tabular}




\begin{tabular}{|l|l|l|}
\hline NO & \multicolumn{1}{|c|}{$\begin{array}{c}\text { The Aspect } \\
\text { Studied }\end{array}$} & \multicolumn{1}{c|}{ Annotation } \\
\hline 3 & $\begin{array}{l}\text { Strategy and } \\
\text { Learning Approach }\end{array}$ & $\begin{array}{l}\text { Pancasila and 1945 Constitution. } \\
\text { The learning strategy used is expository } \\
\text { answach consisting of lecture, question- } \\
\text { answer and discussion. } \\
\text { The use of inquiry approach is still } \\
\text { limited. } \\
\text { The method had not fully suited with } \\
\text { students learning style in order to } \\
\text { facilitate academic achievement of } \\
\text { students who are varied in culture, religion } \\
\text { and social aspects. } \\
\text { Generally students want discussion, role } \\
\text { playing and inquiry. }\end{array}$ \\
\hline 4 & $\begin{array}{l}\text { Source } \\
\text { Learning Material }\end{array}$ & $\begin{array}{l}\text { Learning source and teaching material } \\
\text { used in learning in the form of reading } \\
\text { materials and resources, textbook, internet } \\
\text { source (article and another paper), } \\
\text { magazine/newspaper, and non reading } \\
\text { materials and resources, the use of audio } \\
\text { visual and the utilization of classroom. } \\
\text { Lack of students readiness in preparing } \\
\text { learning material and/or using learning } \\
\text { sources. }\end{array}$ \\
\hline 5 & $\begin{array}{l}\text { Assessment and assignment in the form of paper, } \\
\text { Evaluation } \\
\text { article and group discussion. } \\
\text { Mid Semester Exam Assignment in the } \\
\text { form of Paper/Written Work. } \\
\text { Final Semester Exam Assignment in the } \\
\text { form of performance test (microteaching) } \\
\text { or teaching practice. }\end{array}$ \\
\hline
\end{tabular}

From that finding, it can be revealed that in learning design of Civic Education as vehicle of multicultural education in higher education, there are some learning components which should be given attention such as learning planning summarized in (syllabus and SAP) which is consistent with goal and competence which want to be achieved in learning, learning strategy and approach, learning source and material and learning assessment and evaluation tool. Those learning components should be able to suit with students' need in order to facilitate the academic achievement of students who are varied in cultural, religious, social and economic status aspects.

\section{DISCUSSION}

\section{A. The Development of Multicultural Material through Civic Education Learning in Building Democratic Citizen}

From some materials which had been developed, the concept of multiculturalism become one study which had been taught in Civic Education course in Primary School Teacher Education Department, Faculty of Pedagogy, State University of Jakarta. The concept of multiculturalism review various problems which support ideology, politic, democracy, justice, law enforcement, job opportunity and business, human right, cultural right for community and minority group, ethical and moral principles, level and quality of productivity and various another concepts which is more relevant [9-11]. In addition, multicultural also play role to unite nation culture. One study which ever conducted by Ravitch find that Compare California's pluralistic and New York's particularistic approaches; argues for an education that appreciates diversity and supports commitment to a unified American culture. Multicultural which play role in the effort to unite nation culture is in accordance with their state motto E Pluribus Unum which is similar with Unity in Diversity in Indonesia [12].

This concept is in accord with what had expressed by Blum that multiculturalism comprise an understanding, appreciation and judgment to one's culture and a respect and curiosity about another's ethnic culture [13]. In accord with that terminology, Supardan express that the keywords in this multiculturalism are "diversity" and "appreciation", two words which often confronted so far [12].

For that, there are some multiculturalism elements which should be understood as value to be internalized in education. Blum make sub value of multiculturalism into three groups as follow: (1) assert one' cultural identity, learn and judge one's culture heritage; (2) respect and willing to understand and learn about another ethnics/cultures beside his/her own culture; (3) judge and like the difference in the culture itself, that is, viewing the existence of different culture groups in one's community as positive goodness to be appreciated and maintained [13].

In international research literature, there had been concluded that the power of multicultural education can suppress ethnic conflict in a cultural pluralism society. Hawkins show that multicultural education is very effective to raise awareness about equality, democratic, tolerance and rationality among cultures. It is reported also that multicultural education is very effective to accommodate "power domination" of one ethnic or culture [11].

As shown in finding in the field, development of material on multiculturalism in Civic Education course and make multicultural education course as optional course has been done in Primary School Teacher Education Department, Faculty of Pedagogy, State University of Jakarta. That curricular development is in accord with Mahfud view who assert that it is important to refine Civic Education which had been taught in higher education by incorporating multicultural education such as local culture among regions in it in order that young generation proud as Indonesian nation [14]. In accordance with that view, Budimansyah and Suryadi express that "Civic Education which play important role in multicultural education prepare student to become citizen who has strong commitment and consistent to defend Unitary State of the Republic of Indonesia [15]." Similarly with Tilaar opinion who express that multicultural education in Indonesia aims to foster Indonesian individuals who have their own tribal culture, maintain and develop it, and build Indonesian nation with Indonesian culture as mandated in 1945 Constitution [16]. So multicultural learning both through civic education and Islamic education (and through another subject), should make students to become citizen who are religious but inclusive and pluralist without sacrifice religious basis they believe [17].

From the finding in field, it is revealed that Civic Education can be made to become guidance in competence development process to interact effectively with people from various 
background. The guidance here means from "awareness" phase toward "development" phase. Even according to W/AU, Civic Education can be made to become spearhead in overcoming the problems of nation which is vulnerable to conflict and nation disintegration, lack of nationality spirit to make this country to become nation-state, strengthened togetherness in diversity, grow democratic awareness among citizens, and various problems faced by Indonesian nation. Furthermore, W/USW express that Civic Education has scope comprising at least three important domains namely Civic Education as scholarship study field which play role in developing concepts and theory; Civic Education as curricular program which develop some educational programs and its implementation model in preparing students to become adult human who has character through elementary school until higher education; and Civic Education in social culture which is implemented coherently in society life.

In the context of this study, this view is relevant with Banks idea about multicultural education dimension which consist of five dimensions namely: (1) content integration, (2) the knowledge construction process, (3) an equity pedagogy, (4) and (5) empowering school culture. From those multicultural education dimensions, then three models of multicultural education emerged namely: content-oriented programs; student-oriented programs; and socially-oriented programs [18]. Multicultural education can be seen also from 3 (three) aspects: an idea or concept, an educational reform movement, and a process [19]. In this program, what had been expressed by Saunders about values approach which support development and favorable and the values which less support development and unfavorable are introduced to students [20]. The inculcation of those multicultural values is intended to build citizen who has character and capable to solve the problem peacefully and capable to appreciate the difference [21].

If compared with educational program in Malaysia and Jordan, these two countries also have educational program in responding to the condition of their multicultural country through civic education. It can be seen from the study by Khader, Fakhri R [22]. One of its findings is that national curriculum and civic and citizenship education in Malaysia emphasize the concept of national identity, multiculturalism, tolerance and nation building, whereas curriculum in Jordan basically emphasize loyalty to regime and nation as a whole. Not only Malaysia and Jordan, Canada also had been long time responding to its nation condition which is so multicultural like a mosaic through governmental policy in education, and one of them is through civic education. Related to it, Joshee in his writing titled Multicultural Education, Diversity and Citizenship in Canada give description about the importance of civic education program to become vehicle of multicultural education to strengthened national identity by accommodating internal diversity [23]. Canada is considered quite consistent in inculcating multiculturalism value by introducing multiculturalism "mosaic" policy through citizenship [24]. In addition, the research which was conducted by Soutphommasane Team regarding three studies, namely Multicultural Citizenship Theory, The Need of New
Multicultural Citizenship Theory, Toward The Pluralist Model of Multicultural Citizenship Education. The setting of that study were in Australia and Canada [25]. Similarly, the research conducted by Simon, Amanda conclude Civic Education as new study in developing values, bearing in mind that multiethnic of contemporary society is very important to be developed by civic education which is more complex in accord with conception and basic idea such as equality and inclusion [26]. Even United States had implemented multicultural education in the effort to omit racial discrimination between white people and black people, which aims to develop and maintain national integrity. Barack Husain Obama who was elected to become the 44th President of US from black ethnic is the portrait of United States success in implementing multicultural education [27]. In addition, this research want to reveal that the role of Civic Education as vehicle of multicultural education in curricular domain in higher education is in content and process. Content should be differentiated into two kind's namely formal content and informal content. Formal content cannot be negotiated so the content should be the same for all students and university students in whole schools and higher education which teach Civic Education in Indonesia. Whereas, content informal is contextual depending on environment where students located. However, how citizen behavior occur and formed in learning in various contexts must be differ [28].

Therefore, the way used in developing the material of Civic Education based on multicultural education in higher education is to develop Civic Education content or material in higher education which accommodate material on diversity and contemporary multiculturalism which can be seen from three perspectives namely as instrumentation, practice and idea.

\section{B. The Learning Design of Civic Education as Vehicle of Multicultural Education}

1) The Learning Plan of Civic Education as Vehicle of Multicultural Education

Based on result study in lectures syllabus component of Civic Education based on multicultural education in Primary School Teacher Education Department, State University of Jakarta as part of learning plan, the principles had been made but there are still some which had not done well. As part of learning plan, lectures syllabus contain the aim which want to be achieved, the material presented, teaching tools, and teaching schedule as well as the competence which want to be achieved in learning. Learning plan is a step to prepare teaching and learning activity rationally, systematically and systemically such as determine standard competence and competence indicator which should be possessed by students, determine the material which will be delivered along with its subs, select effective and relevant strategy, prepare teaching material and learning aid in class and make evaluation model to measure the level of success in learning [29].

The other thing which should be considered in making learning plan is that it should be flexible, not rigid, so it can be changed and adjusted with condition and dynamic occurred in learning process. It means that basically learning strategy is learning plan itself. It is in accord with J.R. David who say 
that "learning strategy contain planning." It means that basically strategy is still conceptual about the decisions which will be made in a learning plan [30]. It shows the importance of arranging mature learning plan in order that learning goal can be achieved.

2) The Goal of Civic Education Learning as Vehicle of Multicultural Education

Based on result study in the field, the goal of civic education based on multicultural education in Primary School Teacher Education Department, Faculty of Pedagogy, State University of Jakarta are: First, to foster and develop nationality insight and grow the love toward motherland among students as smart and good citizens in accord with the goal of that course program. Second, to equip and develop student's ability to think critically and reflectively so they are able to become citizens who have awareness of Unitary State of the Republic of Indonesia. Third, to grow and build students awareness so they are able to become democratic and civilized citizens in accord with the ideal of Pancasila and 1945 Constitution.

This finding is parallel with Civic Education task with revitalized paradigm to develop democracy education which carry out three basic function, namely to develop civic intelligence, foster civic responsibility and encourage civic participation. Civic intelligence which is developed to build good citizen not only in rational dimension and intellectual dimension but also in spiritual, emotional and social dimensions so new paradigm of Civic Education has multi dimension characteristic [8]. Based on competence which needs to be developed, multicultural citizen development require the fulfillment of civic competence which has multicultural characteristic. There are three main components which need to be learned in Civic Education namely civic knowledge, civic skills, and civic dispositions [31].

Related to it, The National Standard for Civics and Government formulate the main components of civic competences [32]. Civic knowledge is related to right and duty as citizen. Civic skills comprise intellectual skills and participation skills. The most important intellectual skill to build citizen who is broad minded, effective, and responsible among other is critical thinking skill. Civic disposition indicate in public character and private which is important for maintenance and development of constitutional democracy which is needed to create social capital. Therefore, the thing needed for developing multicultural citizen is the ability to interact and live together with people with language, memory and history background which is not similar [33].

In addition, by referring to the concept of multicultural education based-curriculum, learning program which is developed should be suited with students need and social condition. Multicultural education model developed is directed to some basic competences. First, developing standard and basic academic skills about the values of unity, democracy, justice, freedom, equality and mutual respect in various kinds of diversity. Second, developing social skills in order to grow better understanding about their own cultural and religious background and also another cultural and religious background in society. Third, develop academic skills to analyze and make intelligent decisions about real life problems and issues through a democratic process or dialogical inquiry. Forth, help in conceptualizing and aspiring better society construction, democratic, egalitarian, without discrimination, oppression and violence toward universal human right value [34].

In accordance with analysis of learning goal and civic skills which want to be achieved, then it can be revealed that Civic Education learning based on multicultural education not only inculcate the better understanding of democracy, human right, plurality, respect and tolerance among various community, but also democracy, civilization and multicultural experiences which are manifested through various multicultural civic skills.

\section{3) The Learning Strategy of Civic Education as Vehicle of} Multicultural Education

Learning strategy can be done in macro in the period of one year or in micro in the period of one teaching and learning activity. Based on finding result in the field (interview, documentation and observation), it can be described that learning strategy of Civic Education course based on Multicultural Education in Primary School Teacher Education Department, Faculty of Pedagogy, State University of Jakarta use expository approach and inquiry approach. In general, Civic Education lectures more use (expository approach) namely lecture method, which is supported by question answer, demonstration and discussion. As for inquiry approach also become one approach which is usually used by lecturer in learning but it still very limited.

Related to it, Gerlanch and Ely reveal that there are two kinds of learning strategy, namely Expository Approach and Inquiry Approach. Experiment, small group discussion, problem solving and question-answer methods is very popular to be used in this strategy [35]. Related to it, there must be some learning approach which can be applied and developed. Civic education learning can apply adult learning/andragogy. Its application more emphasize humanistic paradigm, and contextual learning experience in order that learning process become enjoyable, more meaningful, dialog, participative and creative. To achieve that goal, it needs to use learning strategies which capable to make students closer with social reality so they can discover learning to be, learning to do and learning to live together [17]. In addition, the application of integrative multicultural education can also use cooperative learning model. The basic of group formation in efficient cooperative learning by forming non-permanent group with session appointment or face to face session [36].

Therefore, Civic Education learning which aims to build democratic citizen will not be succeeded if it is delivered by undemocratic learning strategy. Civic education with spirit contained in it reject all kinds of strategy which are conflicted with its learning goal.

4) Learning Material and Source of Civic Education as Vehicle of Multicultural Education

Teaching material is learning material and source format which will be given to students. Based on study result, it can be described that Civic Education course as vehicle of Multicultural Education in Primary School Teacher Education Department, Faculty of Pedagogy, State University of Jakarta 
cannot be maximally prepared by lecturer or students themselves. For Civic Education course, students less prepare teaching material in lectures. The lack of student's reference make learning become relatively monotone and democratic and active learning atmosphere is less created.

Whereas learning resource is something which can be used as learning material or origin for someone to study. At least there are five kinds of learning resource, namely human, book/library, mass media, environment (natural environment, historical environment and society environment) and educational media [37]. It is differ from Jerolemik who grouped learning resources into two categories namely: First, reading materials and resources in the form of text, internet resource (article and another paper), magazine/newspaper, etc. Second, non reading material and resource comprising picture, film, recording, fieldtrip and community resource [38]. Based on that view, the use of learning sources which is still less developed in Civic Education based on multicultural education in Primary School Teacher Education Department is non reading material and resources. One of them is the use of natural and community resources which is very important for learning in order to be more meaningful [39].

Therefore, the function of learning resource is very influential to learning outcome because giving easiness and learning experience to students. Thus, learning resource can be defined as media which can be made to become reference in supporting learning easiness [30]. One task of lecturer which is equally important is to search and determine learning resource.

Grounded theory finding in this study reveal that there are some competence which become achievement expected in Civic Education as vehicle of multicultural education in building democratic citizen which is summarized into some main objective and learning orientation namely building good and smart citizen, participative citizen, responsible citizen, and capable to develop living the world life with some core values which are developed into competence which should be possessed by citizen namely being open minded, mutual trust, mutual understanding in diversity, mutual respect, living together with the others, national identity, tolerance of diversity, and conflict resolution.

\section{CONCLUSION}

Based on some study findings which had been explained in earlier discussion, then the concept and implementation of Civic Education learning as vehicle of multicultural education in higher education can be seen from some aspects, two of them are material development and learning design.

- Material development is important part in adjusting learning study with current condition in meeting students' need. Related to this study, material development in Civic Education learning in Primary School Teacher Education Department, Faculty of Pedagogy, State University of Jakarta had started to apply some materials which had been integrated into Civic Education material, such as nation integrity theme, multicultural education concept, relation of multicultural principle and Indonesian nationalism, concept and essence of multiculturalism are seen from philosophical, juridical and empirical aspects. It is in accord with informal content of Civic Education which is contextual which depend on environment where students live.

- Learning design is important aspect in supporting learning process so it should be planned systematically and consistently with learning goal which can be achieved. Related to this study, learning design of Civic Education as vehicle of multicultural education in Primary School Teacher Education, Faculty of Pedagogy, State University of Jakarta had been arranged systematically, but there are many learning components which should be developed among other planning (learning goal, competence which should be achieved), learning material and resource which should utilize natural environment and community so its learning strategy and approach should be varied and innovative.

- The result of grounded theory in this study found some competences which are expected can be achieved in Civic Education learning as vehicle of multicultural education in building democratic citizen and it is summarized into some main objectives namely to build good and smart citizen, participative citizen, responsible citizen, so it can build citizen who is able to "living the world life" with some core values which needs to be developed into open minded, mutual risk, mutual understanding in diversity, mutual respect, living the life together with others, self national identity, and conflict resolution.

\section{ACKNOWLEDGEMENT}

The researcher would like to thank to Civic Education experts, Sociology experts, students and lecturers of Civic Education course who are willing to become respondents in this study.

\section{REFERENCES}

[1] Sudrajat, "Revitalisasi Pendidikan Multikultural Dalam Pembelajaran," Jurnal Pembangunan Pendidikan, vol. 2, no. 1, 2014.

[2] J.J. Cogan and R. Derricot, Citizenship for the 21st Century: An International Perspective on Education. London: Kogan Page, 1998.

[3] D. Kerr, Citezenship Education: an Inernational Comparison, london: National Foundation For Education Research-NFER, 1999.

[4] A. Abdullah, "Model Kurikulum Pendidikan Islam Multikultural di Pondok Pesantren Modern Islam Assalam Surakarta," Varia Pendidikan, vol. 24, no. 1, 2012.

[5] N. Zuhria, Model Pengembangan Pendidikan Kewarganegaraan Multikultural Berbasis Kearifan Lokal (Studi di Perguruan Tinggi Kota Bandung. Disertasi PPS UPI: tidak diterbitkan, 2011.

[6] A. Murtadho, "Mengembangkan Pendidikan Multikultural Dalam Pembelajaran PAI," Al-Tadzkiyyah: Jurnal Pendidikan Islam, vol. 7, 2016.

[7] H. Hernandez, Multicultural Education: A Teacher Guide to Linking Context, Process, and Content. New Jersey \& Ohio: Prentice Hall, 1989.

[8] Sapriya and U.S. Winataputra, Materi dan Pembelajarn PKn SD, Jakarta: Universitas Terbuka, 2010. 
[9] J. Rex, "The Concept Of Multicultural Society". Occasional Paper in Ethnic Relations, No.3, (Centre For Research in Ethnic Relations), 1985.

[10] F. Brian, Contemporary Philosofhy of Social Science: A Multikultural Approach. Oxford: Blackwell, 1996.

[11] P. Suparlan, Menuju Masyarakat Indonesia Yang Multikultural, Makalah, Disajikan pada Simposium Internasional Jurnal Antropologi Indonesia ke-3, Membangun Kembali "Indonesia yang Bhinneka Tunggal Ika", Menuju Masyarakat Multikultural, Universitas Udayana, Denpasar, Bali, 16-19 Juli 2002.

[12] D. Supardan, Pembelajaran Sejarah Berbasis Pendekatan Multikultural dan Perspektif Sejarah Lokal, Nasional, Global, untuk Integrasi Bangsa: Studi Kuasi Eksperimental Terhadap Siswa Sekolah Menengah Umum di Kota Bandung. Disertasi PPS UPI: tidak diterbitkan, 2004.

[13] L.A. Blum, "Antirasisme, Multikulturalisme, dan Komunitas AntarRas: Tiga Nilai yang Bersifat Mendidik bagi Sebuah Masyarakat Multikultural". Dalam May, Larry, Shari Collins-Chobanian, and Kai Wong (Eds). Etika Terapan I: Sebuah Pendekatan Multikultural, 2001

[14] C. Mahfud, Pendidikan Multikultural. Yogyakarta: Pustaka Pelajar, 2010.

[15] D. Budimansyah dan Suryadi, PKn dan Masyarakat Multikultural, Bandung: Program Studi PKn SPs UPI, 2008.

[16] H.A.R. Tilaar, Multikulturalisme, Tantangan-Tantangan Global Masa Depan dalam Transformasi Pendidikan Nasional, Jakarta : Grasindo, 2004.

[17] D. Rosyada, Pendidikan multikultural di indonesia Sebuah pandangan konsepsional, 2014.

[18] J.A. Banks, "Multicultural Education: Historical Development, Dimensions and Practice," Review of Research in Education, vol. 19 1993.

[19] J.A. Banks, Educating Citizens in a Multicultural Society. Teachers College Columbia University New York and London, 1997.

[20] M. Saunders, Multicultural Teaching: Aguide for the classroom, London: McGraw-Hill Company, 1982.

[21] Mariyani, "Peran PKn dalam Menanamkan Nilai-Nilai Multikultura untuk Membentuk Warga Negara Muda Yang Toleran," Civic-Culture: Jurnal Ilmu Pendidikan PKn dan Sosial Budaya, 2018.

[22] F.R. Khader, "The Malaysian Experience in Developing National Identity, Multicultural Tolerance and Understanding through Teaching Curricula: Lessons Learned and Possible Applications in the Jordanian Context. Chairman Dept of Educational Sciences Petra University Amman - Jordan," International Journal of Humanities and Social Science, vol. 2, no. 1, 2012

[23] R. Joshee, Multicultural Education, Diversity, and Citizenship in Canada, OISE, University of Toronto Carla Peck, University of Alberta. Acadia University Ottilia Chareka, St. Francis Xavier University Alan
Sears, University of New Brunswick Working paper for the IALEI Workshop on Multicultural Education Seoul, Korea February 17-19, 2010

[24] D. Supardan, "Keberhasilan Kebijakan Multikulturalisme Kanada dan Tantangannya: Studi Hak Azasi Manusia dalam Perspektif Global,' Jurnal Pendidikan Ilmu Sosial (JPIS), Bandung: FPIPS UPI, 2002.

[25] T. Soutphommasane, "Grounding Multicultural Citizenship: From Minority Rights to Civic Pluralism," Journal of Intercultural Studies, vol. 26, no. 4, pp. 401/416, 2005.

[26] A. Simon, Citizenship Education and Multiculturalism: The Needs of Educators within the Contemporary Multicultural Context. Newman College of Higher Education, 2002.

[27] Z. Arifin, "Pendidikan Multikultural-Religius untuk Mewujudkan Karakter Peserta Didik yang Humanis-Religius," Jurnal Pendidikan Islam, vol. I, No. 1, 2012/1433.

[28] A. Wahab and Sapriya, Teori dan Landasan Pendidikan Kewarganegaraan. Bandung: Alfabeta, 2011.

[29] D. Rosyada, dkk. Buku Panduan Dosen Pendidikan Kewarganegaran (Civic Education). ICCE UIN Syarif Hidayatullah Jakarta Dan The Asia Foundation, 2004

[30] K. Komalasari, Pembelajaran Kontekstual (Konsep dan Aplikasi) Bandung: Refika Aditama, 2010.

[31] M.S. Branson, The Role of Civic Education. Calabasas: CCE, 1998

[32] Center for Indonesia Civic Education/ CICED, Democratic Citizens in a Civic Society: Report of the Conference on Civic Education for Civic Society. Bandung: CICED, 1994.

[33] D.B. Arif, Pengembangan Warga Negara Multikultural Implikasinya Terhadap Kompetensi Kewarganegaraan (Penelitian Grounded Theory dalam Konteks Pendidikan Kewarganegaraan Indonesia). Tesis PPS UPI:tidak diterbitkan, 2008

[34] N. Naim dan A. Sauqi, Pendidikan Multikultural Konsep dan Aplikasi.Yogyakarta: Ar-Ruzz Media Group, 2011

[35] Rahmat dkk., Pembelajaran Pendidikan Kewarganegaraan. Laboratorium Pendidikan Kewarganegaraan-FPIPS UPI, 2009.

[36] Suparmi, "Pembelajaran Kooperatif dalam Pendidikan Multikultural," Jurnal Pembangunan Pendidikan: Fondasi dan Aplikasi, vol. 1, no. 1, 2012.

[37] Sudirman, Interaksi dan Motivasi Belajar Mengajar. Jakarta: Raja Grafindo Persada, 2003

[38] J. Jerolemik, Social studies in Elementary Educatioan. Seventh Edition. New York: Macmillan Publishing Company;London: Collier Macmillan Publishers, 1982

[39] A.H. Herry, Pengembangan Kurikulum dan Pembelajaran (PGSD4407), Modul 7 Jakarta: Universitas Terbuka, 1998. 